\title{
Environmental Quality and Economic Development: is there a Kuznets Curve for Air Pollution in Nigeria?
}

\author{
Abiodun Edward Adelegan ${ }^{*}$, Emmanuel Otu \\ Department of Economics and Development Studies Federal University Otuoke, Otuoke, Bayelsa State, Nigeria
}

*Corresponding Author

Abiodun Edward Adelegan

\section{Article History}

Received: 25.04.2020

Accepted: 03.05.2020

Published: 16.05 .2020

\begin{abstract}
This paper investigated the validity of Environmental Kuznets Curve (EKC) hypothesis in Nigeria using the Autoregressive Distributed Lag model (ARDL) estimated with the Ordinary Least Square (OLS) technique. The study used annual secondary data obtained from the World Bank indicators and the Central Bank of Nigeria for the period under review (1980-2018). Findings from the study support the validity of the EKC hypothesis for $\mathrm{CO}_{2}$ emissions. The study therefore recommended a harmonious environmental and economic policy mix that would engender greater income but keeping the protection of the environment a priority.
\end{abstract}

Keywords: Environmental Kuznets curve, environmental quality, economic development, ARDL,externalities.

\section{INTRODUCTION}

One of the fundamental objectives of any economic system irrespective of its political, social and institutional arrangements is to produce goods and services in such a way that the environment is sustained, in other words, to reduce the tension between economic growth and environmental sustainability. The environment is a store house of resources that are used as inputs in the production system. Also, the environment serves as sink to residuals generated from productive and consumptive activities [1]. The evidence of environmental degradation and its attendant effects is a reality in Nigeria. Environmental threats such as ozone layer depletion, increases carbon dioxide $\left(\mathrm{CO}_{2}\right)$ emissions; desert encroachment and coastal erosion abound in Nigeria [2, 3].

The crux of the matter is to what extent can Nigeria develop and still maintain environmental quality that is sustainable [4]. According to Abubakar [5] sustainable national development is a process of improving the range of opportunities that will enable individual humans and communities to achieve their aspirations and full potentials in a manner that sustains natural resources and the environment for future generations. Ojewunmi [6] opined that the growth of the complex interdependent relationship which engendered growth trajectory has a direct bearing on the environment. Environmental quality is often believed from theory to vary with different stages, pattern and structure of development. There is clear evidence that although economic growth usually leads to environmental deterioration in the early stages of the process, in the end, the best and probably the only way to attain a decent environment in most countries is to become rich [7].

Grossman and Krueger [8] in the seminal work posited that during the early stages of economic development, a country experiences increase environmental degradation which will increase until a certain level of income is reached. At that level, environmental improvement will occur. Omotor [9] lucidly explained this to mean that when agriculture and allied activities as well as light manufacturing dominate the typical economy pollution intensity will be generally low. As the economy moves into heavy industry, pollution intensity increases. As the economy moves further to high technology pollution intensity tends to decline. This produces an inverted U-shaped curve, analogous to that proposed by Kuznets [10] in the relationship that existed between income inequality and average national income. Kuznets hypothesized that economic inequality increases over time and then after a threshold becomes more equal as per capital income increases; hence the income-environment nexus is dubbed the "environmental Kuznets Curve [9].

Copyright @ 2020: This is an open-access article distributed under the terms of the Creative Commons Attribution license which permits unrestricted use, distribution, and reproduction in any medium for non commercial use (NonCommercial, or CC-BY-NC) provided the original author and source are credited. 
Given the importance attached to the income environment relationship, a lot of studies had been carried out to investigate the nature of this crucial relationship [11, 12]. The statistical and econometric evidence of the EKC relationship is mixed and the interpretation thereof ambiguous. The Nigerian economy is pollution intensive and ranked among the top $50 \mathrm{CO}_{2}$ emitter countries in the world [9]. Again, the rise in urbanization coupled with population growth and migration from the Sahel as a result of climate change issues are contributory factors to pollution intensity in Nigeria. It is clear from the foregoing that over-utilization of the ecosystem can further deteriorate the relation between the level of economic growth and emission pollutants $[13,14]$. Against this background, the objective of this paper is to examine the relationship between economic development and environmental quality in Nigeria. For us to achieve the aforementioned objective the following relevant questions are relevant: What is the nature of relationship between development and environmental quality? What is the effect of per capita income on environmental quality? Is the EKC hypothesis hold for Nigeria? Following this introductory section is section 2 which presents some insights from empirical literature and theoretical framework. Section 3 presents the method employed in the study-while section 4 unveils the empirical results and findings, section 5 concludes the paper with policy recommendations.

\section{LiTERATURE REVIEW}

The seminal work of Grossman and Krueger [8] brought to lime light the intricate relationship between economic growth and environmental quality. Following this pioneering research effort, various studies on the incomeenvironment nexus have emerged. Friedl and Getzner [15] investigated the relationship between economic development and $\mathrm{CO}_{2}$ emissions in Australia between 1960 and 1999. The study revealed an N-Shaped relationship between GDP and $\mathrm{CO}_{2}$. Also, from the study a structural break was identified in the mid-seventies due to oil price shocks. Between the periods 1961-2004 [16] investigated the existence of the EKC relation for Tunisia using $\mathrm{CO}_{2}$ and $\mathrm{SO}_{2}$ emissions. The results revealed a long-run cointegration between per capita GDP and the proxies for environmental quality. Also, an inverted U-shaped relation with a turning point of $\$ 1,200$ for $\mathrm{SO}_{2}$ was found. In the same vein, Akbostanci et al. [17] employed co-integration techniques to examine the income environment relation for Turkey. The results revealed a monotonically increasing relationship between $\mathrm{CO}_{2}$ emissions and income in the time series analysis. The panel data analysis indicated an $\mathrm{N}$-shaped relationship for $\mathrm{SO}_{2}$ and PM10 emissions. For now, there are four studies that had investigated the EKC hypothesis for Nigeria. Omisakin [18] examined the EKC hypothesis in Nigeria using $\mathrm{CO}_{2}$ and per capita GDP from 1970-2005. The study revealed that there is no long-run relationship between $\mathrm{CO}_{2}$ per capita and GDP per capita. In addition, the study reputed the inverted U-shaped curve for Nigeria. Using a standard EKC model with four control variables; foreign direct investment, share of manufacturing in GDP, energy consumption and a financial sector variable [19] investigated the EKC relationship for Nigeria. The study found no evidence of the EKC relation instead a U-Shaped relation between $\mathrm{CO}_{2}$ emissions and GDP growth rate was obtained. Chuku [20] investigated the incomeenvironment relation for Nigeria between 1960 and 2008. Standard and nested EKC models were estimated and results obtained from the standard EKC specification revealed an N-relationship suggesting a weak evidence of the existence of EKC. The Nested-EKC model reported an $\mathrm{N}$-shaped relationship between income and $\mathrm{CO}_{2}$ emissions with a turning point at \$237.28. The finding implied that economic developments in Nigeria. Using a fractional cointegration analysis over the period of 1970-2011 [21] investigated the relationship between environmental quality-carbon emissions and economic growth in Nigeria. The study found no significant evidence to support the EKC in Nigeria.

Aslanidis Iranzo [22] using a 2-regime smooth transition regression (STR) model which is a more flexible parametric specification. The authors applied this methodology for 77 non-OECD countries over the period 1971-1997. Though the evidence of EKC could not be ascertained but the results revealed two regimes. The first one is a low income region $\mathrm{CO}_{2}$ emissions accelerate with growth and the second a middle-to-high-income region associated with a deceleration in environmental degradation. Using a panel of 100 countries for the period 1960-1996 [23] could not reject a linear relationship between per capital income and $\mathrm{CO}_{2}$ emission.

Using two indicators for environmental quality, $\mathrm{CO}_{2}$ and $\mathrm{SO}_{2}[9]$ examined the relationship between per capita income and environmental quality for ECOWAS countries. The results of the empirical investigation suggested the existence of environmental Kuznets curves for environmental quality indicators. Factors such as population density, openness and income policy interaction variable were found to affect environmental quality. Ojewunmi [6] investigated the relationship between environmental quality and economic growth in sub-Sahara Africa using a panel analysis over the period 1980-2012. The results revealed that EKC is invalid for the selected countries for some pollutants but valid for others. Also, the study revealed that it may be wrong to generalize the reaction of a single environmental variable to EKC hypothesis as it was found that different pollution emissions may produce different EKC positions. Osabuohien, Efobi and Gitau [24] studied the applicability of the EKC hypothesis in 50 African countries using data from 1995-2010. The empirical results suggested the existence of a long-term relationship between $\mathrm{CO} 2$ and particulate matter emissions jointly with per capita income and other variables. The study recommended the need for African countries to reduce the level of environmental pollution at higher levels of economic development. Apergis and Ozturk [13] focused on income and policies, investigated the existence of EKC hypothesis for 14 Asian countries spanning the period 1990-2011. The authors employed the system Generalized Method Moments (GMM) on panel data set to test the EKC hypothesis. The 
results revealed the presence of an EKC hypothesis. The study recommended reducing greenhouse gas rising from industry, transport and heating.

Taking a bird's view of the literature reviewed thus far, the empirical findings are inconsistent, both for country specific and cross country EKC relationships. The inclusion of $\mathrm{SO}_{2}$ emissions as an indicator of environmental quality coupled with the use of autoregressive distributed lag technique to take care of variables that are $\mathrm{I}(0)$ and $\mathrm{I}(1)$ since the technique can work under such arrangement makes this paper unique from previous attempts.

\section{Ghg emissions in nigria: some stylized facts}

In this subsection, we present the profile of Green House Gas (GHG) emissions in Nigeria. Basically, there are five major contributors to GHG emissions in Nigeria. These are land use change, energy, agriculture, waste and industrial processes as well as product use. Available data from the World Resources Institute [20] reported that Nigeria stands at about half the world average, in line with others in sub-Sahara Africa (SSA) and below middle income countries such as South Africa, Brazil and Mexico. However, in terms of emissions per unit of GDP, Nigeria produces more than twice the world average, above all comparator countries. A total GHG emission in Nigeria is $1.01 \%$ of world total WRI [20].

In 2005, half of the country's emissions came from agriculture, forestry and land use change (AFOLU). The AFOLU sector comprises sub-categories; Livestock, land, aggregated sources and non- $\mathrm{CO}_{2}$ emissions (UNDP (2019). Nigeria's 2014 GHG emissions were primarily from the land-use change and forestry (LUCF) sector as well as the energy sector which accounted for $38.2 \%$ and $32.6 \%$ respectively. (World Resources Institute, Climate Analysis Indicators Tool, 2017). According to FAOSTAT (2018) waste, agriculture and industrial processes (IP) contributed $14.0 \%, 13.0 \%$ and $2.1 \%$ of the country's total emissions. Within LUFC, emissions were basically from degradation and loss of forest land. Available data from Nigeria's First Biennial Update Report (BURI) to the UNFCCC, Submitted in 2018, includes a GHG inventory for the years 2000 to 2015. The report shows that in 2015, the combined emissions from agriculture, forestry, and other land use (AFOLU) were the leading source of GHG emissions (66.9\%), followed by energy $(28.2 \%)$, waste $(3.0 \%)$ and industrial processes and product use (IPPU) $(1.9 \%)$.

Land use change and forestry $\quad-\quad 38.2 \%$

Energy $\quad-\quad 32.6 \%$

Waste $\quad-\quad 14.0 \%$

Agriculture $\quad-\quad 13.0 \%$

Industrial Processes $\quad-\quad 2.1 \%$

Draw a histogram or bar or pie chart to illustrate this.

According to WRI, CAIT data sources, Nigeria's GHG emissions increased by $25 \%\left(98.22 \mathrm{Mt} \mathrm{CO}_{2}\right)$ from 1990 to 2014. The average annual change in total emissions was $1 \%$ while GDP grew $245 \%$ averaging $5.5 \%$ annually. Although GDP grew faster than GHG emissions, in 2014, Nigeria's emissions relative to GDP were 1.6 times the world average, indicating potential for improvement.

On the average Nigeria emitted 50,567.975 kt from 1960-2014. In 2018, a $\mathrm{CO}_{2}$ emission for Nigeria was $110,690 \mathrm{kt}$. Though $\mathrm{CO}_{2}$ emissions fluctuated substantially in recent years, it tended to increase through 1999-2018 period ending at $110,690 \mathrm{kt}$ in 2018 .

\begin{tabular}{|l|l|}
\hline 1990 & 74.72 \\
\hline 2000 & 97.95 \\
\hline 2005 & 101.28 \\
\hline 2010 & 91.04 \\
\hline 2015 & 96.59 \\
\hline 2017 & 1017.57 \\
\hline 2018 & 110.69 \\
\hline
\end{tabular}

\section{Source: BP 2015 - 2018 data of the BP statistical Review of World Energy}

In the energy sector, Nigeria's emissions increased by 32\% from 1990 to 2014 due mainly to other fuel combustion. According to the BUR, oil, natural gas, and biomass are the main sources of energy. Smaller sources of emissions from electricity and heat generation, transportation, manufacturing and construction have increased. Fugitive emissions which results from leaks and other unintended releases of gases are a substantial source of GHG emissions but have decreased since 1990. In line with its Intended Nationally Determined Contribution (INDC), Nigeria is developing projects to reduce or eliminate GHG emissions from gas flaring by 2030 . Nigeria pledged to unconditionally reduce its GHG emissions in 2030 by $20 \%$. The report further stated Nigeria's target to reduce GHG in 2030 by $45 \%$ conditioned upon receipt of international support. 
The key mitigation measures identified by the INDC are: ending gas flaring by 2030, achieving off grid solar PV generation of $13 \mathrm{GW}$, making use of efficient gas generators, achieving $92 \%$ yearly increase in energy efficiency and implementing climate smart agriculture.

\section{Analytical framework}

The nature of the association between environmental quality and economic development in Nigeria is anchored on the EKC literature see $[25,26]$ for oversight. The causal hypothesis is that the relationship between economic development and environmental quality is not monotonic and may swing upwards or downwards when a country reaches a level of development (income) at which people prefer a cleaner environment to higher levels of income. This implies an inverted U-shaped relationship between environmental quality and income.

Three different functional forms are commonly used to analyze this relationship: a linear function (which implies a monotonic relationship), a quadratic function (which implies an inverted U-shaped relationship) and a cubic function (which will simply an N-shaped or a sideways mirrored S-shaped relationship).

Typically, the standard EKC model takes the following form.

$$
\left(\begin{array}{l}
E \\
P
\end{array}\right)=\alpha_{0}+\alpha_{1} \mathrm{t}+\beta_{1}\left(\begin{array}{c}
G D P \\
P
\end{array}\right)+\beta_{2}\left(\begin{array}{c}
G D P \\
P
\end{array}\right)+\frac{\beta}{t}\left(\begin{array}{c}
G D P \\
P
\end{array}\right)+\gamma \frac{\mathrm{X}_{1}}{t} \pm \mu \mathrm{t}
$$

Where $E$ is environmental degradation captured by $\mathrm{CO}_{2}$ emissions, $\mathrm{P}$ is population size, hence $(\mathrm{E} / \mathrm{P})$ is per capita $\mathrm{CO}_{2}$ emissions. (GDP/P) is per capita real GDP and $X_{t}$ is a vector of variables that may often affect environmental quality. $t$ is the deterministic time trend, used as a proxy for technological progress. For various reasons, mainly data availability and small sample sizes, several empirical studies entirely omit the vector $X_{t}$. We did not tow this line for the reasons given above. Thus we did not place the restriction that $\gamma=0$. With this, we can describe the relationship that may be expected to hold between income and the environment with varying signs of $\beta_{\mathrm{t}}$. If $\beta_{1}>0$, and $\beta_{2}=\beta_{3}=0$, then, we have the linear case where the relationship between economic development and environmental quality is monotonically increasing.

If $\beta_{2}>0 . \beta_{3}=0$, then there will be an inverted - U-shaped relationship between emissions and GDP. Finally, if $\beta_{1}>0, \beta_{2}<0$, and $\beta_{3}>0$. Then an $\mathrm{N}$-shaped relationship between emissions per capita and output per capita will be observed. Conversely, Friedl and Getzner [27] show that if these signs are reversed (i.e., $\beta_{1}<0, \beta_{2}>0$, and $\beta_{3}<0$, then a sideways mirrored S-shaped graph will be observed. From these specifications, the tuning point income per capita for which per capita emissions are at their maximum levels is easily derived as:

$$
\left(\frac{G D P}{P}\right)_{\max }=\left(\begin{array}{c}
-\beta 1 \\
2 \beta 2
\end{array}\right)
$$

Where $\beta_{1}$ and $\beta_{2}$ are the parameter estimates for the levels and square of per capita GDP respectively.

\section{Method of Study The Data}

This study employed the use of time series data sourced from the World Bank indicators data, Central Bank of Nigeria's Statistical Bulletin, Economic and Financial Review, and Statement of Accounts as well as the National Bureau of Statistics (NBS). The model for this study uses the Autoregressive Distributed Lag model (ARDL) and the estimation technique is the ordinary least square method.

\section{Model Specification}

In this study, per capital $\mathrm{CO}_{2}$ consumption is the dependent variable while per capital Gross Domestic Product, openness and institutions are the independent variable. To measure the effects of regressors on the regresand, we specify:

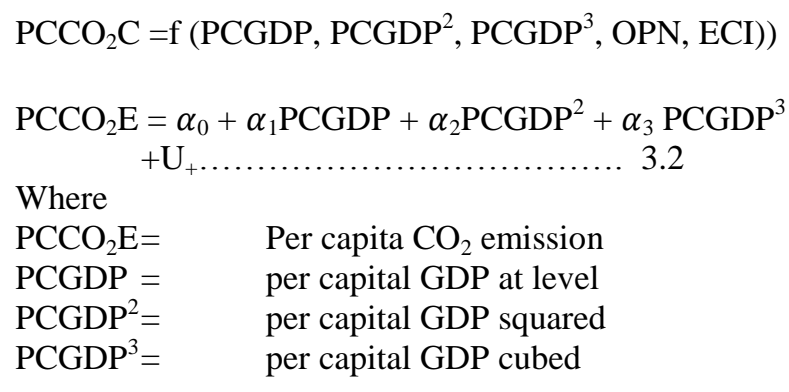

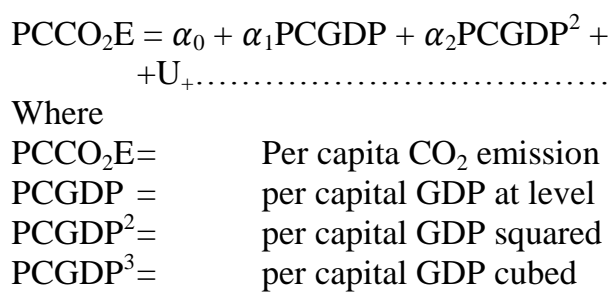




$\begin{array}{lll}\text { OPN } & = & \text { Openness of the economy } \\ \text { INST } & = & \text { Institutions }\end{array}$

Table-3.1: Theory, intuition and expected signs

\begin{tabular}{|l|l|l|}
\hline Variable & Theory and intuition & Sign \\
\hline $\begin{array}{l}\text { Per capital Carbon Dioxide } \\
\left(\mathrm{CO}_{2}\right) \text { emissions }\end{array}$ & This variable measures in metric tons per capita/per annum. & $\begin{array}{l}+/- \\
+/-\end{array}$ \\
\hline Per capital GDP & GDP per capita at level & $+/-$ \\
\hline Per capital GDP squared & Squared GDP per capita & $+/-$ \\
\hline Per capital GDP cubed & Cubed GDP per capita at level & $\begin{array}{l}\text { Nigeria has dirty industry with heavy share of pollutants; the sign of } \\
\text { openness is expected to be positive. }\end{array}$ \\
\hline Openness & $\begin{array}{l}\text { The institutions in Nigeria are presently weak. The incidence of gas flaring } \\
\text { that has become intractable is an indicator of systemic weakness; therefore } \\
\text { we expect the sign of this variable to be positive. }\end{array}$ & + \\
\hline Institutions & \\
\hline
\end{tabular}

\section{Estimation technique; ardl approach for co-integration}

This study employed the autoregressive distributed lag model (ARDL) approach introduced in Pesaran et al. [28] to examine the long run relationship between per capital $\mathrm{CO}_{2}$ emission and economic development, openness, institutions in Nigeria. The reasons for using ARDL is that it has a number of advantages over other methods of estimate long run relationships between variables The first is that it can be applied irrespective of whether underlying independent variables are purely $\mathrm{I}(0)$, purely $\mathrm{I}(1)$ or mutually co-integrated [28]. The second advantage is that it performs better than Engle and Granger [29], Johansen [30] and Philips and Hansen [31] co-integration tests in small samples. The third advantage is that the ARDL approach enables us to estimate an unrestricted conditional error-correction model (UECM) taking each of the variables in turn as dependent variables.

Pesaran and Smith [28] later PSS [32] surmized that a long run association among macroeconomic variables may be investigated by employing the ARDL model under some conditions. After the establishing the stationarity status of each variable, Ordinary Least Square (OLS) may be employed for estimation and identification. Rational estimation and inference can be drawn through the presence of a unique long run alliance that is crucial. Such inferences may be made not only on the long run but also on the short run coefficients, which implies that the ARDL model is correctly augmented to account for contemporaneous correlations between the stochastic terms of the data generating process (DGP). It is concluded that ARDL estimation is possible even where explanatory variables are endogenous. Moreover, ARDL remains valid irrespective of the order of integration of the explanatory variables. But ARDL will collapse if any variable is integrated at $\mathrm{I}(2)$.

Equation (3.2) transformed into an ARDL Model as Shown in 3.3 below $\triangle \mathrm{PCCO}_{2} \mathrm{E}=\alpha_{0}+\alpha_{1} \mathrm{PCGDP}+\alpha_{2} \mathrm{PCGDP}^{2}+\alpha_{3} \mathrm{PCGDP}^{3}+\alpha_{4} \mathrm{OPN}+\alpha_{5} \mathrm{INST}+$ $+\sum_{j=0}^{p} \quad \beta_{1} \Delta \mathrm{PCGDP}+\sum_{j=0}^{p} \quad \beta_{2} \Delta \mathrm{PCGDP}^{2}+\sum_{j=0}^{p} \quad \beta_{3} \Delta \mathrm{PCGDP}^{3}+\sum_{j=0}^{p} \quad \beta_{4} \Delta \mathrm{OPN}+\sum_{j=0}^{p} \quad \beta_{5} \Delta \mathrm{INST}^{2}+\mathrm{e}_{\mathrm{i}}$ ........ 3.3

Where $\mathrm{e}_{\mathrm{i}}$ is the error term, $\alpha_{\mathrm{s}}$ are the long run parameters while $\beta_{\mathrm{s}}$ are the short run parameters to be estimated and $\mathrm{p}=(1,2, \ldots \ldots, 1 \mathrm{c}) . \Delta$ is the first difference operator. An advantage of this model is that it can be used irrespective of whether the explanatory variables exhibit stationarity at level or at first difference or combination of both.

After the completion of ARDL estimation, the next step is to construct an Error Correction Model (ECM) suggested by PSS. Based on the foregoing, the error correction model for equation (3.3) is specified as:

$$
\begin{aligned}
& \Delta \mathrm{PCCO}_{2} \mathrm{E}=\beta_{0}+\sum_{j=0}^{p} \quad \beta_{1} \Delta \mathrm{PCGDP}_{\mathrm{t}-\mathrm{j}}+\sum_{j=0}^{p} \quad \beta_{2} \Delta \mathrm{PCGDP}_{\mathrm{t}-\mathrm{j}}^{2}+\sum_{j=0}^{p} \quad \beta_{3} \mathrm{PCGDP}^{3}+\sum_{j=0}^{p} \quad \beta_{4} \Delta \mathrm{OPN}_{\mathrm{t}-\mathrm{j}}+ \\
& \sum_{j=0}^{p} \quad \beta_{5} \Delta \mathrm{INST}_{\mathrm{t}-\mathrm{j}}+\sum_{j=0}^{p} \quad \beta_{6} \Delta \mathrm{ECMt}_{-1}
\end{aligned}
$$

\section{Result Presentation And Synthesis}

With the adoption of ARDL for the analysis of data, stationarity test was carried out to ensure that none of the variables is integrated at second difference $\{\mathrm{I}(1)\}$. Augumented Dickey Fuller (ADF) and Philips Perron (PP) unit root test were used, and the summary of the result is presented in Table 4.1. 
Table-4.1: Summary of Unit Root Test

\begin{tabular}{|l|l|l|l|}
\hline Variables & ADF & PP & Decision \\
\hline $\mathrm{PCCO}_{2} \mathrm{E}$ & 1.86 & 1.67 & \\
$\mathrm{D}\left(\mathrm{PCCO}_{2} \mathrm{E}\right)$ & $8.06^{*}$ & $13.71^{*}$ & $\mathrm{I}(1)$ \\
\hline PCGDP & $3.93^{* *}$ & $3.86^{* *}$ & $\mathrm{I}(0)$ \\
\hline PCGDP $^{2}$ & $6.43^{*}$ & $6.71^{*}$ & $\mathrm{I}(0)$ \\
\hline PCGDP $^{3}$ & $7.23^{*}$ & $7.51^{*}$ & $\mathrm{I}(0)$ \\
\hline OPEN & 2.32 & 2.25 & \\
D(OPEN $)$ & $4.58^{*}$ & $11.27^{*}$ & $\mathrm{I}(1)$ \\
\hline INST & 2.77 & 2.53 & \\
D(INST) & $5.9 *$ & $12.22^{*}$ & $\mathrm{I}(1)$ \\
\hline
\end{tabular}

Source: Researchers' computation using Eviews

Note: (i) D is the first difference operator (ii) * and ** signifies stationarity at $1 \%$ and $5 \%$ respectively. (iii) ADF and PP critical values at $1 \%$ and $5 \%$ levels are 4.24 and 3.54 respectively. (iv) All values were reported in their absolute terms.

Within the framework of ADF and PP, the growth rate of GDP per capita (PCGDP), its square value (PCGDP ${ }^{2}$ ), and its cubic value $\left(\mathrm{PCGDP}^{3}\right)$ were stationary at level data $\{\mathrm{I}(0)\}$. While carbon emission per capita $\left(\mathrm{PCCO}_{2} \mathrm{E}\right)$, openness (OPEN), and quality of institution (INST) became stationary after their first difference were taken $\{$ I $(1)\}$. With a combination of $\mathrm{I}(0)$ and $\mathrm{I}(1)$ variables, the adoption of ARDL for the analysis of data is thus justified. ARDL with cointegration bound testing was employed. Within the framework, a generic ARDL was first estimated, and coefficient diagnostic of the bound test was carried out to check for the existence of long run equilibrium relationship among the variables of the model. The result of the bound test is presented in Table 4.2.

Table-4.2: Summary of Bound Test

\begin{tabular}{|c|c|c|c|c|}
\hline \multirow{2}{*}{ F-statistic } & \multicolumn{2}{|c|}{$5 \%$ Critical Value } & \multicolumn{2}{c|}{$1 \%$ Critical Value } \\
\cline { 2 - 5 } & Lower Bound & Upper Bound & Lower Bound & Upper Bound \\
\hline 13.97 & 2.39 & 3.38 & 3.06 & 4.15 \\
\hline
\end{tabular}

Source: Researchers' computation using Eviews

From the result in Table 4.2, the value of the F-statistic is greater than the lower and upper bounds at both $5 \%$ and $1 \%$ critical values, and this is an indication of the existence of long run equilibrium relationship among the variables of the model. With this confirmation, further coefficient diagnostic check was carried out for the long run estimate and the Error Correction model (ECM), which is the short run analysis. Their respective results are presented in Table 4.3 and 4.4

Table 4.3: Long-run Estimate

Dependent Variable: $\mathrm{PCCO}_{2} \mathrm{E}$

\begin{tabular}{|c|c|c|c|c|}
\hline Variable & Coefficient & Std. Error & t-Statistic & Prob. \\
\hline PCGDP & 0.002807 & 0.002484 & 1.130155 & 0.2876 \\
\hline PCGDP $^{2}$ & -0.001020 & 0.000609 & -1.674203 & 0.1284 \\
\hline PCGDP $^{3}$ & 0.000358 & $6.68 \mathrm{E}-05$ & 5.356118 & 0.0005 \\
\hline OPEN & -0.007277 & 0.000469 & -15.51681 & 0.0000 \\
\hline INST & -0.160146 & 0.005685 & -28.16794 & 0.0000 \\
\hline C & 1.352752 & 0.028965 & 46.70368 & 0.0000 \\
\hline
\end{tabular}

Source: Researchers' computation using Eviews

In the long run, the current value of GDP per capita exerts a positive insignificant influence on the dependent variable. A unit change in its value can induce 0.003 change in the dependent variable. The squared value of GDP per capita has negative insignificant impact on the dependent variable. A unit change in its value can induce 0.001 change in the dependent variable. While the cubic value of GDP per capita exerts positive significant impact on the dependent variable. A unit change in its value can induce 0.0004 change in the dependent variable. Also, trade openness and quality of institution have negative significant impact on the dependent variable. 
Table-4.4: ARDL Error Correction Regression

Dpendent Variable: $\left(\mathrm{PCCO}_{2} \mathrm{E}\right)$

\begin{tabular}{|c|c|c|c|c|}
\hline Variable & Coefficient & Std. Error & t-Statistic & Prob. \\
\hline $\mathrm{D}\left(\mathrm{PCCO}_{2} \mathrm{E}(-1)\right)$ & 0.730415 & 0.112048 & 6.518786 & 0.0001 \\
\hline $\mathrm{D}\left(\mathrm{PCCO}_{2} \mathrm{E}(-2)\right)$ & 0.181384 & 0.083549 & 2.170992 & 0.0580 \\
\hline D(PCGDP) & 0.020776 & 0.002368 & 8.772383 & 0.0000 \\
\hline D(PCGDP(-1)) & 0.004883 & 0.001773 & 2.754641 & 0.0223 \\
\hline $\mathrm{D}\left(\mathrm{PCGDP}^{2}\right)$ & -0.004557 & 0.000538 & -8.476052 & 0.0000 \\
\hline $\mathrm{D}\left(\operatorname{PCGDP}^{2}(-1)\right)$ & -0.002243 & 0.000255 & -8.812946 & 0.0000 \\
\hline $\mathrm{D}\left(\mathrm{PCGDP}^{2}(-2)\right)$ & -0.001033 & 0.000138 & -7.471506 & 0.0000 \\
\hline $\mathrm{D}\left(\mathrm{PCGDP}^{3}\right)$ & 0.000315 & 4.41E-05 & 7.143998 & 0.0001 \\
\hline $\mathrm{D}\left(\mathrm{PCGDP}^{3}(-1)\right)$ & -0.000176 & $1.63 \mathrm{E}-05$ & -10.77714 & 0.0000 \\
\hline $\mathrm{D}\left(\mathrm{PCGDP}^{3}(-2)\right)$ & $-9.60 \mathrm{E}-05$ & $1.17 \mathrm{E}-05$ & -8.190109 & 0.0000 \\
\hline $\mathrm{D}\left(\mathrm{PCGDP}^{3}(-3)\right)$ & $-5.25 \mathrm{E}-05$ & $8.84 \mathrm{E}-06$ & -5.947644 & 0.0002 \\
\hline $\mathrm{D}(\mathrm{OPEN})$ & -0.000834 & 0.000698 & -1.194709 & 0.2627 \\
\hline $\mathrm{D}(\mathrm{OPEN}(-1))$ & 0.009661 & 0.001117 & 8.651027 & 0.0000 \\
\hline $\mathrm{D}(\mathrm{OPEN}(-2))$ & 0.006756 & 0.000926 & 7.298121 & 0.0000 \\
\hline $\mathrm{D}(\mathrm{INST})$ & -0.077719 & 0.009267 & -8.386385 & 0.0000 \\
\hline D(INST(-1)) & 0.244391 & 0.020919 & 11.68292 & 0.0000 \\
\hline $\mathrm{D}(\operatorname{INST}(-2))$ & 0.160733 & 0.014716 & 10.92235 & 0.0000 \\
\hline $\mathrm{D}(\operatorname{INST}(-3))$ & 0.076426 & 0.013597 & 5.620876 & 0.0003 \\
\hline $\operatorname{CointEq}(-1)^{*}$ & -2.016825 & 0.157974 & -12.76683 & 0.0000 \\
\hline
\end{tabular}

$\mathrm{R}^{2}=0.96, \mathrm{D} \cdot \mathrm{W}=2.25$

Source: Researchers' computation using Eviews

The first period and second period lag of carbon emission per capita have positive significant impact on the current level of carbon emission per capita. The magnitude of their respective coefficients is an indication that a unit change in these variables can induce 0.73 and 0.18 change in the dependent variable. The current value of per capita GDP and its one period value have positive significant impact on carbon emission per capita. A unit change in the current value of GDP per capita and its one period lag induce 0.02 and 0.04 change on the dependent variable respectively. The squared value of the current value of GDP per capita, its first period lag, and second period lag have negative significant impact on the dependent variable. A unit change in their respective values will bring about $0.004,0.002$, and 0.001 change on the dependent variable. Also, the cubic value of the current value of GDP per capita has positive significant impact on the dependent variable, while its first period lag, second period lag, and third period lag have negative significant impact on the dependent variable. The current value of trade openness has negative insignificant impact on the dependent variable, while its first period lag, second period lag have positive significant impact on the dependent variable. A unit change in their respective values will bring about $0.0008,0.009$, and 0.006 change on the dependent variable. Furthermore, the current value of the quality of institution has negative significant impact on the dependent, while its first period lag, second period lag, and third period lag have positive significant impact on the dependent variable. A unit change in their respective values will bring about $0.077,0.244,0.16$, and 0.078 change on the dependent variable respectively. The error correction term $\left\{\operatorname{CointEq}(-1)^{*}\right\}$ is negative and significant; and this is an indication of a satisfactory speed of adjustment. Coefficient of correlation $\left(\mathrm{R}^{2}\right)$ of 0.96 is an indication that $96 \%$ change in the dependent variable is accounted for by changes in the independent variables taken together.

In the long run, the current value of GDP per capita exerts a positive insignificant influence on the dependent variable. A unit change in its value can induce 0.003 change in the dependent variable. The squared value of GDP per capita has negative insignificant impact on the dependent variable. A unit change in its value can induce 0.001 change in the dependent variable. While the cubic value of GDP per capita exerts positive significant impact on the dependent variable. A unit change in its value can induce 0.0004 change in the dependent variable. Also, trade openness and quality of institution have negative significant impact on the dependent variable.

From the estimated results, in the long run per capita income was insignificant but the coefficient was positively signed while the coefficient of $\mathrm{GDP}^{2}$ was negative. In addition, the coefficient of $\mathrm{GD}^{3}$ was positively signed. In summary, we had a case of positive, negative and positive signs for the level, squared and cubed per capita income. The results validate the Environmental Kutznets curve hypothesis. This simply means there is an inverted U-shaped curve for capita $\mathrm{CO}_{2}$ emissions in Nigeria. In the same vein, the negative sign attached to the $\mathrm{GDP}^{2}$ is also an indication of existence of EKC hypothesis in Nigeria. The result is in line with findings of Krueger [8] which validates the standard EKC hypothesis. 
The optimum turning point value of US\$138,000 for $\mathrm{CO}_{2}$ which fell outside the original data is not strange with EKC phenomenon $[11,20,9,6]$. Interpreting the EKC at face value may be precarious. This is premised on the fact that it could suggest economic growth is what matters and it should be accorded priority by governments while relegating environmental protection to the future.

The income variables are significant in explaining short run changes in $\mathrm{CO}_{2}$ emission per capita in Nigeria. In the long run and short run estimates, openness and institutions indicates negative and significant relationship. The negative sign is rather surprising contrary to a priori expectation. In reality we know that the Nigeria is a net importer of so many goods hence trade openness is expected to engender $\mathrm{CO}_{2}$ emission. As for institutions, they are not yet performing optimally in spite of the negative relationship between institutions and per capita $\mathrm{CO}_{2}$ emissions. This means that trade openness does not suggest incidence of environmental hazards in Nigeria. This suggests that pollution haven hypothesis does not hold in Nigeria contrary to [20] results for Nigeria and [33] result for china. Again, the results for institutions suggest that as institution improves environmental quality declines in Nigeria.

Residual diagnostic and stability check were also carried out to check for the stability and reliability of the model. The results indicate that the model is free from the problem of serial correlation and heteroscedasticity (see Appendix II and III). The residual normally test is satisfactory as it indicated that the residual is normally distributed (see Appendix I). Furthermore the stability tests indicate that the model is stable and devoid of error of misspecification (see Appendix IV and V).

\section{CONCLUSION AND RECOMMENDATIONS}

This study attempted to reinvestigate whether the EKC hypothesis hold for Nigeria by examining the relationship between environmental degradation and economic development. The study used secondary annual time series data sourced from the World Bank indicators as well as the Central Bank of Nigeria over the period 1970-2018. Trade openness and quality of institutions were included as explanatory variables in the model. The study employed the Autoregressive Distributed Lag model with Ordinary Least Squares as the estimation technique. The Augmented Dickey Fuller procedure was employed to examine stationary of the variables and the bound test for co-integration procedure was employed to examine the existence of co- integration among the variables. Empirical findings from the bound test revealed that there is a long-run relationship between the variables. Environmental degradation is highly responsive to changes in per capita income, trade openness and quality of institutions.

The trade-off between environmental protection and economic productivity is always a very crucial decision for policy makers and stakeholders. By virtue of the fact that economic activities will continue to take place in the environment, the findings of direct and statistically significant effects of real per capital GDP, openness and institutional quality on environmental degradation in the short run and long run has implications for policy makers.

\section{RECOMMENDATIONS}

1. A reinvigoration of policy reforms that are growth enhancing and environmental preserving are germane for Nigeria.

2. Strict restriction is placed on the activities of multinational corporations and other firms importing carbon-intensive products to the country.

3. Environmental related institutions should be strengthened to enable them apply appropriate penalties on earring firms that ran afoul of laid down environmental rules and regulations.

4. The inverted U-shaped income curve calls for more stringent policy measure that is necessary for pollution reduction.

5. The results revealed that oil revenue, openness, exchange rate and $\mathrm{CO}_{2}$ and economic development are jointly determined in Nigeria. Energy policy should not be formulated in isolation. Government's effort should be approached through an integrated energy-environment-development model.

\section{REFERENCES}

1. Egbon, M. (1994). Social Responsibility and The Nigerian Mass Media: Struggles and Tactics for A Balanced Media Coverage of Crises. Media Review, 16-30.

2. Gul'nar, O.K., Sopilko, N.Y., and Ilerittslay, N.I. (2019). Republic of Turkey gas complex development: Problems and Prospects. International Journal of Energy Economics and Policy, 9(1), 346-355.

3. Bekturganova, M., Satybaldin, A., \& Yessekina, B. (2019). Conceptual framework for the formation of low-carbon development: Kazakhstan's experience. International Journal of Energy Economics and Policy, 9(1), 48.

4. Enyoghasim, M. O., Anochiwa, L., Agbanike, F. T., Uwazie, I. U., Kalu, E. U., Onwuka, O. K., ... \& Ogbonnaya, I. O. (2019). Oil Exploration and Exploitation in Nigeria and the Challenge of Sustainable Development: An Assessment of the Niger Delta. International Journal of Energy Economics and Policy, 9(4), 369. 
5. Boyi, A. A. (2013). Education and sustainable national development in Nigeria: challenges and way forward. Mediterranean Journal of Social Sciences, 4(8), 147-147.

6. Sunday, O. J. (2016). Environmental Kuznets curve hypothesis in sub-Saharan African countries: evidence from panel data analysis. International Journal of Environment and Pollution Research, 4(1), 39-51.

7. Beckerman, W. (1992). Economic growth and the environment: Whose growth? Whose environment?. World development, 20(4), 481-496.

8. Grossman, G. M., \& Krueger, A. B. (1991). Environmental impacts of a North American free trade agreement (No. w3914). National Bureau of Economic Research.

9. Omotor, G.D. (2016). Economic growth and emissions; Testing the environmental kutznets curve hypothesis for ecowas countries. CEEPA Discussion paper 63.

10. Aslanidis, N. (2009). Environmental Kuznets curves for carbon emissions: A critical survey.

11. Stern, D. N. (2004). The present moment in psychotherapy and everyday life (norton series on interpersonal neurobiology). WW Norton \& Company.

12. Cole, M.A., \& Neumayer, E. (2005). Environmental Policy and the environmental Kutznets curve: Can developing countries escape the detrimental consequences of economic growth? In p. Dauvergne (Ed.). International Handbook of Environmental Politics: 298-318. Cheltenham and Northampton: Edward Elgar.

13. Apergis, N., \& Ozturk, I. (2015). Testing for environmental that Kutznets curve hypothesis in Asian countries. Ecological indicators 52 pp 16-22.

14. Cumming, G. S., Buerkert, A., Hoffmann, E. M., Schlecht, E., von Cramon-Taubadel, S., \& Tscharntke, T. (2014). Implications of agricultural transitions and urbanization for ecosystem services. Nature, 515(7525), 50-57.

15. Friedl, B., \& Getzner, M. (2003). Determinants of CO2 emissions in a small open economy. Ecological economics, 45(1), 133-148.

16. Fodha, M., \& Zaghdoud, O. (2010). Economic growth and pollutant emissions in Tunisia: an empirical analysis of the environmental Kuznets curve. Energy Policy, 38(2), 1150-1156.

17. Akbostanc1, E., Türüt-Aşık, S., \& Tunç, G. İ. (2009). The relationship between income and environment in Turkey: is there an environmental Kuznets curve?. Energy policy, 37(3), 861-867.

18. Omisakin, O., Adeniyi, O., \& Omojolaibi, A. (2009). Foreign direct investment, trade openness and growth in Nigeria. Journal of Economic Theory, 3(2), 13-18.

19. Bello, A. K., \& Abimbola, O. M. (2010). Does the level of economic growth influence environmental quality in Nigeria: a test of environmental Kuznets curve (EKC) hypothesis. Pakistan Journal of Social Sciences, 7(4), 325329.

20. Chuku, A. (2011). Economic development and environmental quality in Nigeria: Is there an environmental Curve? MPRA, 30195.

21. Ogundipe, A., \& Alege, P. O. (2013). Interest rate pass-through to macroeconomic variables: The Nigerian experience. International Journal of Economics and Finance, 5(10).

22. Aslanidis, N., \& Iranzo, S. (2009). Environment and development: is there a Kuznets curve for CO2 emissions?. Applied Economics, 41(6), 803-810.

23. Azomahou, T., Laisney, F., \& Van, P. N. (2006). Economic development and CO2 emissions: a nonparametric panel approach. Journal of Public Economics, 90(6-7), 1347-1363.

24. Osabuohien, E. S., Efobi, U. R., \& Gitau, C. M. W. (2014). Beyond the environmental Kuznets curve in Africa: evidence from panel cointegration. Journal of Environmental Policy \& Planning, 16(4), 517-538.

25. Kuznets, S. (1955). Economic growth and income inequality. The American economic review, 45(1), 1-28.

26. Caviglia-Harris, J. L., Chambers, D., \& Kahn, J. R. (2009). Taking the "U" out of Kuznets: A comprehensive analysis of the EKC and environmental degradation. Ecological Economics, 68(4), 1149-1159.

27. Friedl, B., \& Getzner, M. (2003). Determinants of CO2 emissions in a small open economy. Ecological economics, 45(1), 133-148.

28. Pesaran, M. H. (2001). Shin. Smith, RJ.

29. Allege, O.P. and Ogundipe, A.A. (2013). Environmental quality and economic growth in Nigeria: A fractional cointegration analysis. International Journal of Development and Sustainability, 2(2).

30. Johansen, S. (1991). Estimation and hypothesis testing of cointegration vectors in Gaussian vector autoregressive models. Econometrica: journal of the Econometric Society, 1551-1580.

31. Hansen, B. E., \& Phillips, P. C. (1990). Estimation and inference in models of cointegration: A simulation study. Advances in Econometrics, 8(1989), 225-248.

32. Pesaran, M. H., Shin, Y., \& Smith, R. J. (2001). Bounds testing approaches to the analysis of level relationships. Journal of applied econometrics, 16(3), 289-326.

33. Ang, A., Hodrick, R. J., Xing, Y., \& Zhang, X. (2009). High idiosyncratic volatility and low returns: International and further US evidence. Journal of Financial Economics, 91(1), 1-23. 
APPENDIX

Residual Normality Test

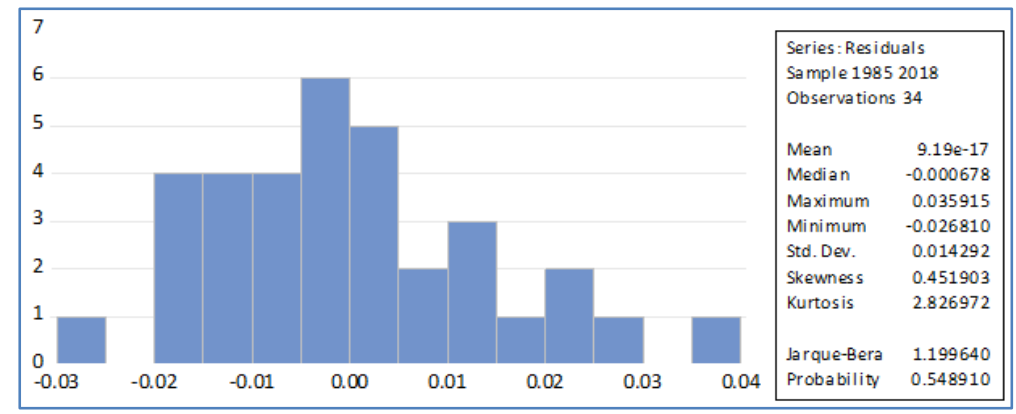

\begin{tabular}{|l|c|c|c|}
\hline II Breusch-Godfrey Serial Correlation LM Test: & \\
\hline F-statistic & 0.484576 & Prob. F(2,7) & 0.6352 \\
\hline Obs*R-squared & 4.134837 & Prob. Chi-Square(2) & 0.1265 \\
\hline
\end{tabular}

\begin{tabular}{|l|c|c|c|}
\hline \multicolumn{4}{|l|}{ III Heteroskedasticity Test: Breusch-Pagan-Godfrey } \\
\hline F-statistic & 0.551901 & Prob. F(24,9) & 0.8819 \\
\hline Obs*R-squared & 20.24448 & Prob. Chi-Square(24) & 0.6828 \\
\hline Scaled explained SS & 1.295793 & Prob. Chi-Square(24) & 1.0000 \\
\hline
\end{tabular}
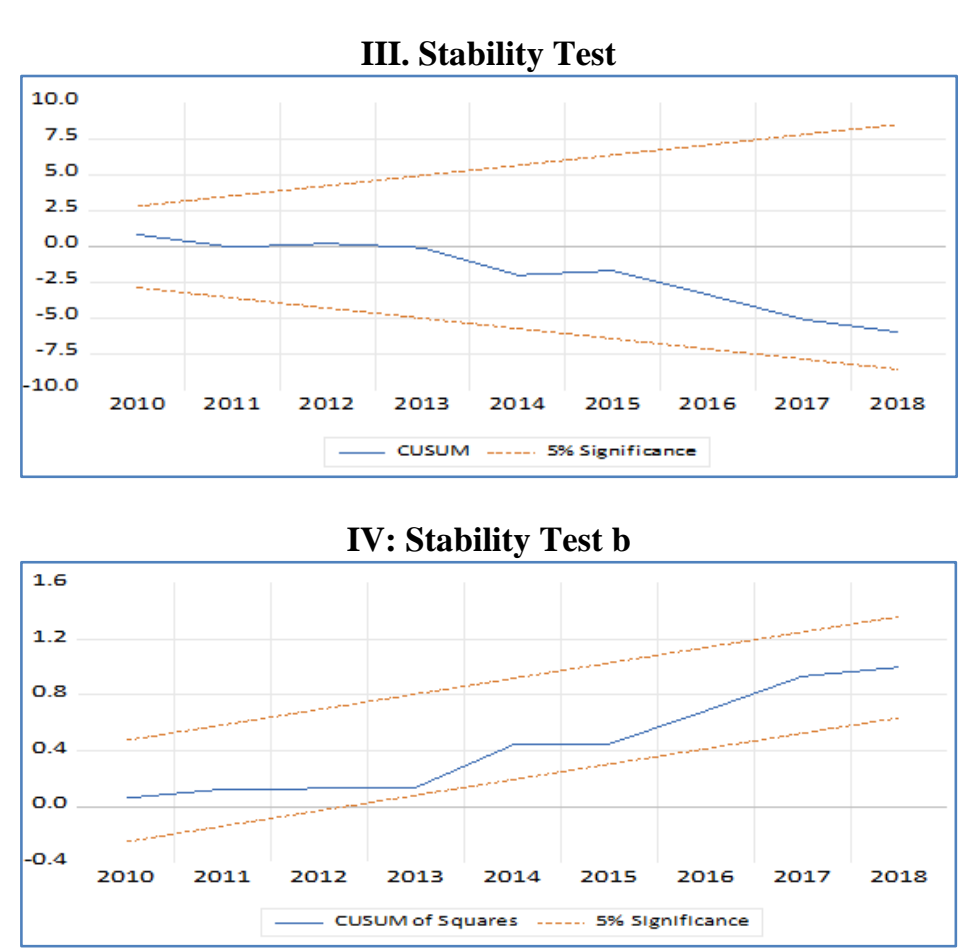

\begin{tabular}{|l|c|c|c|}
\hline \multicolumn{4}{|c|}{ V: Ramsey Reset Test } \\
\hline & Value & Df & Probability \\
\hline t-statistic & 0.146999 & 8 & 0.8868 \\
\hline F-statistic & 0.021609 & $(1,8)$ & 0.8868 \\
\hline
\end{tabular}

